\title{
Development of Corn-Derived Nanoparticles as Mass-Producible Bionanoparticles with Anticancer Activity
}

\section{Daisuke Sasaki}

Tokyo University of Science

Kosuke Kusamori

Tokyo University of Science

Makiya Nishikawa ( $\nabla$ makiya@rs.tus.ac.jp)

Tokyo University of Science

\section{Research Article}

Keywords: corn, cancer therapy, drug delivery, plant-derived nanoparticles, immunostimulation

Posted Date: July 20th, 2021

DOl: https://doi.org/10.21203/rs.3.rs-709895/v1

License: (c) (i) This work is licensed under a Creative Commons Attribution 4.0 International License.

Read Full License 


\section{Abstract}

Recent studies have shown that plant-derived nanoparticles (NPs) contain biologically active molecules and have potential applications as therapeutic agents or delivery carriers for bioactive molecules. In this study, we selected corn as a material for plant-derived NPs as corn is inexpensive to grow and is massproduced globally, and these characteristics are similar to those of plant-derived NPs, which are easy to prepare and can be produced at high yields and low costs. Super sweet corn was homogenized in water to obtain corn juice, which was then centrifuged, filtered through a $0.45 \mu \mathrm{m}$-pore size syringe filter, and ultracentrifuged to obtain corn-derived NPs (cNPs). cNPs obtained were approximately $80 \mathrm{~nm}$ in diameter and negatively charged $(-17 \mathrm{mV})$. cNPs were taken up by various types of cells, including colon 26 tumor cells and RAW264.7 macrophage-like cells, with selective reduction of the proliferation of colon26 cells. Moreover, cNPs induced tumor necrosis factor-a release from RAW264.7 cells. cNPs and RAW264.7 in combination significantly suppressed the proliferation of colon26/fluc cells. Daily intratumoral injections of cNPs significantly suppressed the growth of subcutaneous colon26 tumors in mice, with no significant body weight loss. These results indicate excellent anti-tumor activity of cNPs.

\section{Introduction}

Nanoparticles (NPs), including liposomes and lipid emulsions, particularly those having diameter of approximately $100 \mathrm{~nm}$, have been developed and used as delivery carriers for various pharmaceutical agents [1]. The properties and functions of these synthetic NPs can be easily modulated and controlled by altering their size or surface modification with functional molecules [2, 3]. However, the preparation and development of these NPs for clinical applications is a complex and expensive process [4, 5]. Recently, extracellular vesicles (EVs), such as exosomes and microvesicles, have been recognized as a novel area of research for the development of NPs. They are released from mammalian cells and play important role in intercellular communications by carrying biologically active molecules, such as lipids, mRNAs, and microRNAs [6]. Researchers have attempted to elucidate the functions and therapeutic potential of EVs, and demonstrated the presence of disease-specific EVs and their potential as drug delivery carriers $[7,8]$. Although the development of EV-based therapeutic systems is highly suggested for disease treatment owing to their excellent function and high biocompatibility, but low productivity of EVs greatly limits their clinical applications $[9,10]$.

In addition to these studies, some researchers have revealed the existence of NPs in edible plants and isolated them as edible plant-derived NPs (epNPs) [11]. These epNPs have been prepared from various edible plants, such as grapefruit [12], ginger [13], grape [14], apple [15], and broccoli [16], and they shared common characteristics, including nanometer size, ease of preparation, and mass production at low cost. Furthermore, epNPs have been reported to contain biologically active molecules, such as polyphenols [13] and microRNAs $[14,17]$, and have been used to deliver anti-cancer agents $[18,19,20]$ and small interfering RNA $[21,22,23,24]$ after encapsulation. Therefore, epNPs are anticipated as novel therapeutic agents or drug delivery carriers alternative to synthetic NPs or EVs. 
Corn (Zea mays) is the most widely grown grain crop throughout the world. Corn is one of the most important food crops and one of the top grains produced among the world's top seven cereals [25]. It provides many vitamins and essential minerals along with fibers [26], and it is an accessible source of energy due to its low cost and mass production in the world. Therefore, we speculated that NPs derived from corn could solve the problems of high cost and complex process of synthetic NPs and low productivity of EVs. Furthermore, corn contains vitamins, essential minerals, microRNAs, and xanthophylls, such as lutein and zeaxanthin $[27,28,29]$. A previous report showed potent anticancer activity of lutein and zeaxanthin [30]. Collectively, besides being cost effective, NPs prepared from corn are likely novel functional and bioactive NPs containing microRNAs and xanthophylls. However, there have been no studies on NPs prepared from corn. Therefore, in the present study, we prepared and evaluated the characteristics, functions, and biological activities of corn-derived NPs (cNPs). Moreover, we examined the anticancer activity of cNPs in tumor-bearing mice.

\section{Results}

\section{Preparation and characterization of cNPs}

Figure 1A shows the process of preparation of cNPs from homogenized corn juice using sucrose cushion ultracentrifugation method. DLS analysis showed that cNPs were uniformly sized with an average diameter of approximately $80 \mathrm{~nm}$ and a zeta potential of approximately $-17 \mathrm{mV}$ (Fig. 1B and Table 1). TEM images revealed that cNPs have a hollow structure (Fig. 1C). In addition, the number of cNPs collected from $100 \mathrm{~g}$ of edible portion of corn was approximately $2 \cdot 10^{13}$ (Table 1 ), indicating the ease of preparation and mass production of cNPs.

\section{Cellular Uptake Of Dii-labeled Cnps (Dup: Abstract ?)}

We examined the cellular uptake of cNPs. Figure 2A shows the confocal microscopic images of colon26, $\mathrm{NIH} 3 \mathrm{~T} 3$, and RAW264.7 cells after addition of Dil-labeled cNPs. The red fluorescence signals derived from Dil-labeled cNPs were detected in all cell types (Fig. 2A), indicating efficient uptake of cNPs by these cells. To quantitatively evaluate the cellular uptake of cNPs, the mean fluorescence intensity (MFI) of cells after $3 \mathrm{~h}$ incubation with Dil-labeled cNPs or PC-Lip (control NPs) was calculated. Dil-labeled cNPs were taken up most efficiently by colon26 cells, whereas Dil-labeled PC-Lip were most efficiently taken up by RAW264.7 cells (Fig. 2B). We elucidated the uptake mechanism of cNPs in colon26 cells using endocytosis inhibitors, including M $\beta C D, C P Z$, EIPA, and Filipin III. M $\beta C D$, an inhibitor of cholesteroldependent endocytosis, significantly inhibited the uptake of Dil-labeled cNPs in colon26 cells; however, $\mathrm{CPZ}$, EIPA, and Filipin III did not. These results suggested involvement of cholesterol-dependent pathway in the uptake of cNPs by colon26 cells (Fig. 2C, D).

\section{Effect Of Cnps On Cell Number And Proliferation}


We evaluated the effect of cNPs on the number of colon26, NIH3T3, and RAW264.7 cells after $24 \mathrm{~h}$ of incubation. The number of colon26 tumor cells was significantly reduced at a concentration of 500 $\mu \mathrm{g} / \mathrm{mL}$ or higher of cNPs contrary to normal (NIH3T3) and immune (RAW264.7) cells that lined up at a concentration of $500 \mu \mathrm{g} / \mathrm{mL}$ (Fig. 3A). Figure 3B shows the number of cells against time after incubating them with cNPs at a concentration of $1000 \mu \mathrm{g} / \mathrm{mL}$; cNPs significantly suppressed the proliferation of colon26 cells compared to that of NIH3T3 and RAW264.7 cells, which were not affected.

\section{Effect of cNPs on cell cycle and apoptosis of colon26 tumor cells}

Since the proliferation of colon26 tumor cells was significantly inhibited by cNPs, the effect of cNPs on cell cycle of colon26 cells was examined. Figure 4A shows cell cycle phases of colon26 cells with or without $24 \mathrm{~h}$ incubation with cNPs at varying concentrations. The proportion of the G1 phase in colon26

cells treated with cNPs decreased in a concentration-dependent manner in contrast to the proportion of the $\mathrm{G} 2$ and $S$ phases that increased with cNPs treatment. These results suggested that cNPs induced cell cycle arrest at the $\mathrm{G} 2$ phase in colon26 cells, leading to a low proportion of the $\mathrm{G} 1$ phase and a high proportion of the S/G2 phases.

To elucidate further, colon2 6 cells were stained with PI at 1, 3, and $6 \mathrm{~h}$ after addition of cNPs. Flow cytometry analysis showed that the proportion of dead cells in the vehicle group did not change significantly at any time point, whereas it was increased in the cNPs group in a time-dependent manner (Fig. 4B).

\section{Cytokine Release From Raw264.7 Cells}

The immunological activity of cNPs, being a xenobiotic product, was determined by examining cytokine release from RAW264.7 cells after addition of cNPs. RAW264.7 cells significantly released the proinflammatory cytokine TNF-a after incubation with cNPs (Fig. 5A), though no significant release of anti-inflammatory cytokine IL-10 was detected (Fig. 5B).

\section{Combined effect of cNPs and RAW264.7 cells on the proliferation of colon26/fluc cells}

To examine whether the cNPs-induced responses in RAW264.7 cells affect the proliferation of tumor cells, the number of colon26/fluc cells was evaluated after co-culture with RAW264.7 cells and cNPs treatment (Fig. 6A). The number of colon26/fluc cells decreased when co-cultured with RAW264.7 cells in a cell number-dependent manner. In addition, the cell number was further reduced by adding cNPs. Moreover, colon26/fluc cells and RAW264.7 cells were separately cultured using Transwell culture plates (Fig. 6B). The findings demonstrated that RAW264.7 cells or cNPs reduced the number of colon26/fluc cells, and their combination further reduced the number. These results indicated that cNPs suppressed the proliferation of colon26/fluc cells by direct and indirect mechanisms through activation of immune cells.

\section{Antitumor Effect Of Cnps In Tumor-bearing Mice}


Further, we examined the effect of cNPs on tumor growth in tumor-bearing mice. Figure 7A shows the tumor size against time in colon26 tumor-bearing mice. cNPs significantly suppressed tumor growth in a dose-dependent manner. The tumor volume was approximately $910 \mathrm{~mm}^{3}$ and $340 \mathrm{~mm}^{3}$ at cNPs concentrations of $1000 \mu \mathrm{g} / \mathrm{mL}$ and $3000 \mu \mathrm{g} / \mathrm{mL}$, respectively, which were significantly smaller than that in the control group (approximately $1260 \mathrm{~mm}^{3}$ ). Body weight tended to decrease in the control and 1000 $\mu \mathrm{g} / \mathrm{mL}$ cNPs groups, probably due to tumor burden; however, the weight was maintained in $3000 \mu \mathrm{g} / \mathrm{mL}$ cNPs group (Fig. 7B). Figure 7C shows the skin surface of the injection site after subcutaneous injection of PBS, alum, or cNPs. Alum was used as a positive control to induce inflammation, and therefore the group showed erythema and edema at the injection site, however, these effects were not observed in cNPs groups.

\section{Discussion}

Human cell-derived EVs and synthetically prepared NPs, including liposomes, have potential application as drug delivery carriers that can improve the therapeutic index of various biologically active compounds. However, these carriers are lacking one or more properties required for such applications, including ease of preparation, low cost, and large-scale and reproducible production. Interestingly, the cNPs prepared in the present study satisfied these requirements as they were prepared on a large scale (Table 1) from inexpensive materials using a simple preparation process (Fig. 1A), and were uniform in size similar to liposomes (Fig. 1B, Table 1). We obtained 2.7 $10^{10} \mathrm{EVs}$ from the supernatant of a 24-h culture of 6.1 . $10^{7}$ mouse melanoma B16-BL6 cells, which were reported to release large quantity of EVs among various types of cells (data not shown). However, the yield of cNPs was much higher than that of EVs collected from cell cultures. In addition, the properties of cNPs were nearly constant between different preparations (unpublished data), indicating high reproducibility in production. Thus, the findings of the study suggested cNPs as good candidates for drug delivery.

In general, NPs are taken up by cells via endocytosis; the pathways can be broadly categorized as clathrin-dependent endocytosis occurring in the non-lipid raft membrane domain, and phagocytosis and micropinocytosis occurring in the mixed membrane domains, depending on the cell membrane domains involved. Caveolae-dependent and cholesterol-dependent endocytosis pathways occur in the lipid raft domain [31, 32]. The uptake pathways of epNPs have been evaluated in previous studies. For example, the uptake of ginger-derived NPs by colon26 cells was not inhibited by CPZ or amiloride [13], whereas the uptake of grapefruit-derived NPs by RAW264.7 cells was significantly inhibited by CPZ [33]. The results of the present study demonstrated that cNPs were preferentially taken up by colon26 cells compared to noncancerous cells (Fig. 2A, B). Since M $B C D$ is an inhibitor of cholesterol-dependent endocytosis pathway at the lipid raft domain, this pathway might be partly involved in the uptake of cNPs by colon26 cells (Fig. 2C, D). It has been reported that cNPs have a lipid bilayer membrane structure (Fig. 1C), though not studied in detail to date with respect to lipid composition. A previous report showed that the lipid composition of the edible part of corn, which was used for the preparation of cNPs, is $52.8 \%$ triglycerides, $18.4 \%$ glycolipids, and $28.8 \%$ phospholipids [34]. Considering this as the lipid composition of cNPs, it is 
suggested that the hydrophobic interaction of the lipid bilayer of cNPs with the lipid rafts on the cell surface could contribute to the uptake of cNPs. In addition, it has been reported that cancer cells contain higher levels of lipid rafts than their normal non-tumorigenic counterparts, which contribute to oncogenic signaling and promote tumor progression in cancer [35], as evidenced by human breast cancer cell line MCF-7 having more lipid rafts than human breast epithelial cell line MCF-10A [36]. These findings provide sufficient basis for efficient uptake of cNPs by colon26 cells due to the presence of adequate lipid rafts.

The present study involved three types of cells to demonstrate biological activities of cNPs. The results showed that cNPs inhibited the proliferation of tumor cells more efficiently than that of non-cancerous cells (Fig. 3A, B). This effect might be related to high proliferation rate of cancer cells and efficient cellular uptake of cNPs by tumor cells (Fig. 2B). NPs derived from plants other than corn have been reported to exhibit biological activities. For example, various plant sap-derived NPs have been reported to exhibit antiproliferative activity of varying extent in various tumor cell lines [37]. Additionally, citrus limon-derived NPs were reported to induce TNF-related apoptosis-inducing ligand-mediated cell death [38]. High proliferation rate of cancer cells is related to the accelerated expression of proliferation-related proteins [39]. A recent study reported that survivin, a cell proliferation-related protein, was expressed in colon cancer cells but not in normal colon [40], and siRNA targeting survivin exhibited a great anti-proliferative activity [41]. These studies are suggestive of the contribution of differences in the expression levels of proliferation-related proteins in anti-proliferative activity of cNPs.

epNPs have been reported to contain various biologically active molecules $[13,14,16,17]$. Lutein and zeaxanthin, the xanthophylls present in corn $[28,29]$, are known to exhibit antitumor effects through regulation of cell cycle or cell apoptosis [42-44]. It has been reported that zeaxanthin induced cell cycle arrest at the G2/M phase and apoptosis through the ROS-mediated MAPK, AKT, NF-KB, and STAT3 signaling pathways [43]. High-performance liquid chromatography analysis in the present study confirmed the presence of lutein and zeaxanthin in cNPs (data not shown). Our results are consistent with these studies because addition of cNPs resulted in cell cycle arrest and apoptosis in colon 26 cells (Fig. 4), indicating that xanthophylls could be responsible for biological activities of cNPs, including antitumor activity. In addition, recent studies have reported that microRNAs are upregulated in plants in response to growth process or external stimuli [45], including corn [27]. Interestingly, microRNAs, including miR156 and miR396, have been detected in the serum of corn-fed pigs [46]. These exogenous microRNAs may regulate "cross-kingdom" gene expression in other species, and plant-derived NPs containing these exogenous microRNAs are thought to play an important role in gene regulation. In recent studies, plantderived microRNAs, such as miR156, miR159, and miR167, suppressed the proliferation of enterocytes or breast cancer $[47,48,49]$. Thus, microRNAs encapsulated in cNPs have potential to induce cell cycle arrest in cancer cells. Further studies are needed to confirm the relationship between anti-tumor activity and biologically active molecules in cNPs.

Immune cells, including RAW264.7 cells, release cytokines upon stimulation with pathogen-associated molecular patterns (PAMPs) or Toll-like receptor (TLR) agonists. For example, TLR9 agonists such as CpG oligodeoxynucleotides were recognized by TLR9, followed by the release of IL- 6 and TNF-a from TLR9- 
positive cells [50]. Cytokines play important roles in host defense and homeostasis, and several attempts have been made to treat various diseases with cytokines [51,52]. There have been several reports on epNP-induced cytokine production $[13,14,16,53,54]$. For example, ginger- and ginseng-derived NPs induced IL-10 production in RAW264.7 cells [13], and TNF-a and IL-6 production in macrophage cells [54]. In the present study, we demonstrated that cNPs induced the release of TNF-a from RAW264.7 cells (Fig. 5). However, the detailed mechanism of cytokine production by cNPs was not known in this study. Previous studies reported that TLR4 recognized ginseng-derived NPs as PAMPs, thereby affecting the cascade of the TLR/myeloid differentiation factor 88-dependent signaling pathway, followed by the release of TNF-a in macrophages [54]. These findings are suggestive of a similar mechanism for the release of TNF-a following cNPs addition, however, the detail mechanism needs to be examined. In addition, ginseng-derived NPs polarized tumor-associated macrophages to the M1 type and exhibited antitumor effect through TNF-a production [55] in the tumor. In the present study, indirect antitumor effect of cNPs through activation of RAW264.7 cells was observed (Fig. 6). Therefore, cNP-induced immune activation can be used to treat cancer in the future.

Anti-tumor activity of materials in tumor-bearing mice can be evaluated through directly injecting them intratumorally. Using a colon26 tumor-bearing xenograft mouse model, we demonstrated that cNPs could significantly suppress tumor growth with minimal adverse effects (Fig. 7). The in vitro studies suggested that cNPs suppressed tumor growth in mice by inhibiting the proliferation of colon26 cells (direct effect) and through TNF-a production by activation of macrophages and other immune cells infiltrating into the tumor (indirect effect). These two effects could synergistically or additively contribute to the marked in vivo antitumor effect of cNPs.

\section{Methods}

\section{Materials}

Fetal bovine serum (FBS) was obtained from Biosera (East Sussex, UK); nonessential amino acid solution (NEAA), chlorpromazine (CPZ), sodium phosphotungstate, and $4 \%$ paraformaldehyde phosphate buffer solution (PFA) were obtained from Nacalai Tesque, Inc. (Kyoto, Japan). Phosphatidylcholine (PC), cholesterol, and phosphatidylethanolamine were kindly provided by Nippon Fine Chemical Co., Ltd. (Tokyo, Japan). Chloroform, methanol, penicillin-streptomycin-L-glutamine solution (×100) (PSG), and propidium iodide (PI) were obtained from Wako Pure Chemical Industries, Ltd. (Osaka, Japan). Methylbeta-cyclodextrin (MBCD) was obtained from Tokyo Chemical Industry Co., Ltd. (Tokyo, Japan). Ethylisopropyl amiloride (EIPA) was obtained from R\&D Systems, Inc. (Minneapolis, MN, USA). Filipin III was obtained from Santa Cruz Biotechnology, Inc. (Santa Cruz, CA, USA). Imject Alum Adjuvant (alum) was obtained from Thermo Fisher Scientific (Waltham, MA, USA). Dulbecco's modified Eagle's medium (DMEM) and Roswell Park Memorial Institute (RPMI) 1640 medium were obtained from Nissui Pharmaceutical Co., Ltd. (Tokyo, Japan). All other chemicals used were of the highest commercially available grade. 


\section{Animals}

Eight-week-old BALB/c female mice were purchased from Sankyo Labo Service Co., Inc. (Tokyo, Japan) and maintained under specific pathogen-free conditions. The protocols for experiments involving animals were approved by the Institutional Animal Experimentation Committee of the Tokyo University of Science. All experiments involving animals were conducted in accordance with the principles and procedures outlined in the National Institutes of Health Guide for the Care and Use of Laboratory Animals and the ARRIVE guidelines,.

\section{Cell Culture}

Murine macrophage-like cell line (RAW264.7), murine colon adenocarcinoma cell line (colon26), and firefly luciferase (fluc) stably expressing-colon26 (colon26/fluc) cells [56] were obtained from Professor Yoshinobu Takakura (Department of Biopharmaceutics and Drug Metabolism, Graduate School of Pharmaceutical Sciences, Kyoto University, Kyoto, Japan), and cultured in RPMI medium supplemented with $10 \%$ heat-inactivated FBS and PSG at $37^{\circ} \mathrm{C}$ in humidified air containing $5 \% \mathrm{CO}_{2}$. Murine fibroblast (NIH3T3) cell line (RCB2767) was provided by the Riken BRC through the National BioResource Project of the MEXT/AMED (Ibaraki, Japan) and cultured in DMEM supplemented with $10 \%$ heat-inactivated FBS and $\mathrm{PSG}$ at $37^{\circ} \mathrm{C}$ in humidified air containing $5 \% \mathrm{CO}_{2}$.

\section{Preparation Of Pc Liposome (Pc-lip)}

PC, cholesterol, and phosphatidylethanolamine were mixed at a molar ratio of 10:5:1 and dissolved in 2 $\mathrm{mL}$ chloroform in a round-bottom flask. A lipid film was formed on the wall surface of the flask by solvent evaporation under reduced pressure using a vacuum pump in a water bath. Then, $1 \mathrm{~mL}$ PBS was added, and crude PC liposomes were prepared by sonication at $70^{\circ} \mathrm{C}$ for 2 min using an ultrasonic cleaner (Sono Cleaner, Kaijo, Tokyo, Japan) [57]. They were extruded 5 times through Whatman Nuclepore Track-Etched Membrane with $100 \mathrm{~nm}$ pore size (Cytiva, Tokyo, Japan) at $70^{\circ} \mathrm{C}$. After centrifugation at $10,000 \times \mathrm{g}$ for 10 min to remove aggregates, PC-Lip were obtained from the supernatant.

\section{Preparation Of Cnps}

Super sweet corn was purchased from a local fresh market and washed thoroughly with distilled water. The edible portion of corn $(100 \mathrm{~g})$ was vigorously homogenized with $100 \mathrm{~mL}$ of distilled water using a food processor for $2 \mathrm{~min}$. The homogenized juice was sequentially centrifuged at 2,000 $\mathrm{g}$ for $20 \mathrm{~min}$, $5,000 \cdot \mathrm{g}$ for $30 \mathrm{~min}$, and $10,000 \cdot \mathrm{g}$ for $1 \mathrm{~h}$ at $4^{\circ} \mathrm{C}$. The supernatant was filtered through a $0.45 \mu \mathrm{m}$-pore size syringe filter (Minisart NML, Sartorius, Göttingen, Germany) to exclude rough residues. Approximately $38 \mathrm{~mL}$ of the filtered sample was added to $2 \mathrm{~mL}$ of $60 \%$ sucrose solution in a tube, and then ultracentrifuged at $100,000 \cdot \mathrm{g}$ for 120 min at $4^{\circ} \mathrm{C}$ using Optima XL-K with an SW28 rotor (Beckman Coulter, 
Inc., Brea, CA, USA). The supernatant was carefully removed from the top, and the fraction (approximately $2 \mathrm{~mL}$ ) containing yellow-colored cNPs that was present just above the $60 \%$ sucrose solution was collected carefully without disturbing the sucrose solution.

\section{Characterization Of Cnps}

The particle size and zeta potential of cNPs were measured by dynamic light scattering (DLS) using an ELSZ-2000ZS instrument (Otsuka Electronics Co., Ltd, Osaka, Japan). The particle number was measured using a ZetaView Laser Light Scattering Microscope (Particle Matrix GmbH, Microtrac, Meerbusch, Germany). For transmission electron microscopy (TEM) imaging, a drop of cNPs was deposited onto the surface of a carbon-coated copper grid and negatively stained with $1 \%$ sodium phosphotungstate for 3 min, and the sample was dried at room temperature (approximately $22^{\circ} \mathrm{C}$ ). Then, the sample was observed using an H-7650 TEM (Hitachi High-Tech Co., Ltd, Tokyo, Japan) operated at 100 kV. The protein concentration of cNPs was measured by the Bradford assay [58], and used to standardize the concentration of cNPs.

\section{Fluorescent Labeling Of Nps}

cNPs were labeled with a fluorescent lipophilic dye, 1,1'dioctadecyl-3,3,3',3'-tetramethylindocarbocyanine perchlorate (Dil; Thermo Fisher Scientific). In brief, $0.1 \mathrm{mg} / \mathrm{mL}$ Dil solution $(10 \mu \mathrm{L})$ was added to 1000 $\mu \mathrm{g} / \mathrm{mL} \mathrm{cNPs}(1 \mathrm{~mL})$, and the mixture was incubated for $30 \mathrm{~min}$ at $37^{\circ} \mathrm{C}$. Dillabeled cNPs were then purified using 100-kDa ultrafiltration (Amicon Ultra-15, Merck KGaA, Darmstadt, Germany). Dil-labeled PCLip was prepared in a similar manner.

\section{Cellular Uptake Of Dii-labeled Cnps}

Colon26, NIH3T3, and RAW264.7 cells were seeded in 4-well chambered cover glass (IWAKI; AGC Techno Glass Co., Ltd., Chiba, Japan) at a density of $1 \cdot 10^{5}$ cells/well and cultured overnight at $37^{\circ} \mathrm{C}$. The medium was then replaced with fresh culture medium containing $350 \mu \mathrm{g} / \mathrm{mL}$ Dil-labeled cNPs. After $3 \mathrm{~h}$ of incubation, the cells were fixed with $4 \%$ PFA for $30 \mathrm{~min}$ on ice, and the cells were washed three times with PBS. Subsequently, Vectashield Antifade Mounting Medium with DAPI (Vector Laboratories Inc., Burlingame, CA, USA) was added. The cells were imaged using a Leica SP8 laser scanning confocal microscope (Leica, Wetzlar, Germany) using the LAS X Life Science software. For flow cytometric analysis, the cells fixed with 4\% PFA were collected using a cell scraper, and then filtered through a $70 \mu \mathrm{m}$ cell strainer (Becton Dickinson). Cellular uptake of Dil-cNPs or PC-Lip was quantitatively analyzed using a BD FACSCalibur flow cytometer (Becton Dickinson, San Jose, CA, USA) and FlowJo software ver8.7 (Becton Dickinson). 


\section{Elucidation Of Cellular Uptake Pathway Of Cnps}

To elucidate the cellular uptake pathways of cNPs, endocytosis inhibitors (10 mM MBCD, $30 \mu \mathrm{M} \mathrm{CPZ}, 40$ $\mu \mathrm{M}$ EIPA, and $0.5 \mu \mathrm{g} / \mathrm{mL}$ Filipin III) were added to colon 26 cells and incubated for $40 \mathrm{~min}$ at $37^{\circ} \mathrm{C}$. Dillabeled cNPs were then added to the cells and incubated for $3 \mathrm{~h}$ at $37^{\circ} \mathrm{C}$. The cells were fixed on a glass chamber slide using 4\% PFA for fluorescence imaging under a confocal microscope. Cellular uptake of Dil-cNPs was quantitatively analyzed using a BD FACSCalibur flow cytometer and FlowJo software ver8.7, as described above.

\section{Cell Number And Proliferation Assay}

Colon26, NIH3T3, and RAW264.7 cells were seeded in 96-well culture plate at a density of $5 \cdot 10^{3}$ cells/well and incubated for $24 \mathrm{~h}$ at $37^{\circ} \mathrm{C}$. Culture medium was then replaced with fresh medium containing various concentrations of cNPs. After $24 \mathrm{~h}$ of incubation, cell number was measured using the Cell Counting Kit-8 (Dojindo Laboratories, Kumamoto, Japan). The experiment was repeated except the medium was replaced with fresh medium containing $1000 \mu \mathrm{g} / \mathrm{mL} \mathrm{cNPs}$. The cell number was measured using the Cell Counting Kit- 8 after $6,12,24$, and 48 h of incubation.

\section{Cell Cycle Analysis}

Colon 26 cells were seeded in 6-well culture plate at a density of $1 \cdot 10^{5}$ cells and incubated for $24 \mathrm{~h}$. The cells were washed with PBS, and cNPs at concentrations of 250,500 , and $1000 \mu \mathrm{g} / \mathrm{mL}$ were added to them. After $24 \mathrm{~h}$ incubation, the cells were washed with PBS and fixed with $70 \%$ ethanol at $4^{\circ} \mathrm{C}$ for $3 \mathrm{~h}$. PI $(50 \mu \mathrm{g} / \mathrm{mL})$ was added to the cells, which were then incubated for $30 \mathrm{~min}$ at $4^{\circ} \mathrm{C}$ in the dark. The cells were analyzed using a BD FACSCalibur flow cytometer, and cell cycle analysis was performed using the FlowJo software ver8.7.

\section{Apoptosis Assay}

Colon 26 cells were seeded in 6-well culture plate at a density of $1 \cdot 10^{5}$ cells and incubated for $24 \mathrm{~h}$. The cells were washed with PBS, and cNPs at a concentration of $1000 \mu \mathrm{g} / \mathrm{mL}$ were added to them. The cells were collected using a cell scraper after 1,3 , and $6 \mathrm{~h}$ of incubation. Immediately, PI solution $(50 \mu \mathrm{g} / \mathrm{mL})$ was added to the cells, which were then incubated for $5 \mathrm{~min}$ at $4^{\circ} \mathrm{C}$ in the dark. The cells were analyzed using a BD FACSCalibur flow cytometer, and the proportion of dead cells was calculated using the FlowJo software ver8.7.

\section{Cytokine Measurement By Elisa}


RAW264.7 cells were seeded in 96-well culture plate at a density of $1 \cdot 10^{4}$ cells/well and incubated for 24 h. The medium was replaced with fresh medium with or without cNPs at various concentrations. After 24 $h$ incubation, the concentration of tumor necrosis factor (TNF)- $a$ and interleukin (IL)-10 in the supernatant were measured using Mouse TNF- $a$ ELISA MAX Deluxe Set (BioLegend, San Diego, CA, USA) and Mouse IL-10 Uncoated ELISA kit (Thermo Fisher Scientific, Waltham, MA, USA), respectively.

\section{Effect of cNPs and RAW264.7 cells on the proliferation of colon26/fluc cells}

Colon26/fluc cells were seeded in 12-well culture plate at a density of $1 \cdot 10^{5}$ cells/well and incubated for $24 \mathrm{~h}$. RAW264.7 cells (with varying numbers) and $1000 \mu \mathrm{g} / \mathrm{mL} \mathrm{cNPs}$ were added to colon26/fluc cells. After $24 \mathrm{~h}$ incubation, cells were washed three times with PBS. Subsequently, the cells were lysed using $100 \mu \mathrm{L}$ cell lysis buffer and incubated for $3 \mathrm{~h}$ on ice for complete lysis. Luciferase activity in cell lysates was measured using Picagene luciferase assay kit (Toyo B-Net Co., Ltd., Tokyo, Japan). In addition to this, colon26/fluc cells were seeded in the lower chamber of Transwell cell culture plates at a density of 1 $\cdot 10^{5}$ cells/well. After $24 \mathrm{~h}$ incubation, RAW264.7 cells ( $1 \cdot 10^{5}$ in number) and cNPs at a concentration of

$1000 \mu \mathrm{g} / \mathrm{mL}$ were added to the insert (upper chamber). After $24 \mathrm{~h}$ of incubation, colon26/fluc cells in the lower chamber were washed three times with PBS and lysed using $100 \mu \mathrm{L}$ of cell lysis buffer. Luciferase activity in cell lysates was measured as described above.

\section{Anti-tumor effect of cNPs in a subcutaneous xenograft mouse model}

To prepare a subcutaneous tumor xenograft mouse model, colon26 cells suspended in PBS $\left(1 \cdot 10^{6}\right.$ cells $/ 100 \mu \mathrm{L}$ ) were subcutaneously injected into the back area of BALB/c mice. When the tumor size reached $50 \mathrm{~mm}^{3}$, the mice were randomly assigned to three different treatment groups, and then saline or cNPs (50 or $150 \mu \mathrm{g} / \mathrm{shot}$ ) was injected daily into the tumor for 21 days. Tumor size and body weight of the mice were measured at the time of the sample injection. Tumor volume was calculated as follows: volume $=1 / 2 L^{2}$, where $L$ is the long diameter and $W$ is the short diameter of the tumor [59]. At the end point of the experiment, mice were euthanized under isoflurane anesthesia.

\section{Evaluation of the skin inflammation in mouse after cNPs injection}

The hair on the back area of BALB/c mice was removed using a clipper, and then $50 \mu \mathrm{L}$ of PBS (vehicle), alum (40 mg/mL aluminum hydroxide and $40 \mathrm{mg} / \mathrm{mL}$ magnesium hydroxide), or cNPs (1000 or 3000 $\mu \mathrm{g} / \mathrm{mL}$ ) was subcutaneously injected. The injection site was then photographed after $24 \mathrm{~h}$. After the experiment, mice were euthanized under isoflurane anesthesia.

\section{Statistical analysis}

Statistical differences were evaluated by one-way analysis of variance (ANOVA) followed by the Dunnett's test for multiple comparisons or Student's t-test for comparison between two groups. Statistical significance was set at $p<0.05$. 


\section{Declarations}

\section{Acknowledgements}

The authors are grateful to DKSH Japan K.K. (Tokyo, Japan) for supporting us regrading measurements involving ZetaView, Naofumi Fukata (Nippon Fine Chemical Co. Ltd., Takasago, Hyogo, Japan) for the preparation of liposomes, and Koji Tsuchiya (Research Institute for Science and Technology, Tokyo University of Science, Noda, Chiba, Japan) for kind support in TEM imaging.We would like to thank Editage (www.editage.com) for English language editing.

\section{Funding}

M. Nishikawa received research funding from Ono Pharmaceutical Co., Ltd.

\section{Declaration of interest}

The authors declare no conflicts of interest.

\section{References}

1. Allen, T. M. \&Cullis, P. R. Liposomal drug delivery systems: from concept to clinical applications. Drug Deliv. Rev.65, 36-48 (2013).

2. Cabral, H., Matsumoto, Y., Mizuno, K., Chen, Q., Murakami, M., Kimura, M., Terada, , Kano, M. R., Miyazono, K., Uesaka, M., Nishiyama, N. \&Kataoka, K.Accumulation of sub-100 nm polymeric micelles in poorly permeable tumours depends on size.Nat. Nanotechnol.6,815-823(2011).

3. Tanhaei, A., Mohammadi, M., Hamishehkar, H.\& Hamblin, M. R., Electrospraying as a novel method of particle engineering for drug delivery vehicles. Control. Release330, 851-865(2021).

4. Chountoulesi, M., Naziris, N., Pippa, N. \&Demetzos, C. The significance of drug-to-lipid ratio to the development of optimized liposomal formulation. Liposome Res.28,249-258 (2018).

5. Alarcón, K.P.M., Voltan, A. R., Santos,B.F.,Moro,I.J.,Souza,F.O.,Chorilli, M., Soares,C.P.,Santos, A.G.D.,Giannini, M.J.S.M.\&Almeida,A.M.F. Highlights in nanocarriers for the treatment against cervical cancer, Highlights in nanocarriers for the treatment against cervical cancer. Sci. Eng. $C$. Mater. Biol. Appl.80,748-759 (2017).

6. Takakura, Y., Matsumoto, A.\&Takahashi, Y. Therapeutic application of small extracellular vesicles (sEVs): Pharmaceutical and pharmacokinetic challenges. Pharm. Bull.43,576-583 (2020).

7. Martínez,M.C.\&Andriantsitohaina, R. Extracellular vesicles in metabolic syndrome. Res. 120,16741686 (2017).

8. Yong, T., Zhang, X., Bie, N., Zhang, H., Zhang, X., Li, F., Hakeem, A., Hu, J., Gan, L., Santos, H.A.\&Yang, $X$. Tumor exosome-based nanoparticles are efficient drug carriers for chemotherapy. Commun.10,3838 (2019). 
9. Jang,S.C.,Kim, O.Y.,Yoon,C.M., Choi,D.S.,Roh,T.Y., Park, J., Nilsson, J., Lötvall, J., Kim, Y.K.\&Gho, Y.S. Bioinspired exosome-mimetic nanovesicles for targeted delivery of chemotherapeutics to malignant tumors.ACS Nano7,7698-710 (2013).

10. Lu, M.\& Huang, Y. Bioinspired exosome-like therapeutics and delivery nanoplatforms.Biomaterials242,119925 (2020).

11. Dad,H.A., Gu,T.W.,Zhu,A.Q., Huang,L.Q.\&Peng, L.H. Plant exosome-like nanovesicles: Emerging therapeutics and drug delivery nanoplatforms. Ther. 29,13-31 (2021).

12. Wang, Q., Ren, Y., Mu, J., Egilmez, N. K., Zhuang, X., Deng, Z., Zhang, L., Yan, J., Miller, D.\&Zhang, H. G. Grapefruit-derived nanovectors use an activated leukocyte trafficking pathway to deliver therapeutic agents to inflammatory tumor sites.Cancer Res.75,2520-2529 (2015).

13. Zhang, M., Viennois, E., Prasad, M., Zhang, Y., Wang, L., Zhang, Z., Han, M. K., Xiao, B., Xu, C., Srinivasan, S.\& Merlin, D. Edible ginger-derived nanoparticles: anovel therapeutic approach for the prevention and treatment of inflammatory bowel disease and colitis-associated cancer.Biomaterials101,321-340 (2016).

14. Ju, S., Mu, J., Dokland, T., Zhuang, X., Wang, Q., Jiang, H., Xiang, X., Deng, Z. B., Wang, B., Zhang, L., Roth, M., Welti, R., Mobley, J., Jun, Y., Miller, D.\& Zhang, H. G. Grape exosome-like nanoparticles induce intestinal stem cells and protect mice from DSS-induced colitis. Ther.27,1345-1357 (2013).

15. Fujita, D., Arai, T., Komori, H., Shirasaki, Y., Wakayama, T., Nakanishi, T.\&Tamai, I. Apple-derived nanoparticles modulate expression of organic-anion-transporting polypeptide (OATP) 2B1 in Caco-2 cells. Pharm.15,5772-5780 (2018).

16. Deng, Z., Rong, Y., Teng, Y., Mu, J., Zhuang, X., Tseng, M., Samykutty, A., Zhang, L., Yan, J., Miller, D., Suttles, J.\&Zhang, H. G.Broccoli-derived nanoparticle inhibits mouse colitis by activating dendritic cell AMP-activated protein kinase. Ther.25,1641-54 (2017).

17. Xiao, J., Feng, S., Wang, X., Long, K., Luo, Y., Wang, Y., Ma, J., Tang, Q., Jin, L., Li, X.\&Li, M. Identification of exosome-like nanoparticle-derived microRNAs from 11 edible fruits and vegetables. PeerJ6,e5186 (2018).

18. Wang, G., Zhuang, X., Mu, J., Deng, Z. B., Jiang, H., Zhang, L., Xiang, X., Wang, B., Yan, J., Miller, D.\&Zhang, H. G. Delivery of therapeutic agents by nanoparticles made of grapefruit-derived lipids. Commun. 4,1867(2013).

19. Zhang, M., Xiao, B., Wang, H., Han, M. K., Zhang, Z., Viennois, E., Xu, C.\&Merlin, D.Edible ginger-derived nano-lipids loaded with doxorubicin as a novel drug-delivery approach for colon cancer therapy. Ther.24, 1783-1796 (2016).

20. Tang, Z., Jun, Y., Lv, Y., Li, Y., Zhang, Z., Tao, M., Chen, X., He, J., Zhang, L.\&Wang, Q. L. Aptamerconjugated and doxorubicin-loaded grapefruit-derived nanovectors for targeted therapy against HER2 + breast cancer. Drug Target.28,186-194 (2020).

21. Zhang, M.,Wang, X., Han, M. K., Collins, J. F.\&Merlin, D. Oral administration of ginger-derived nanolipids loaded with siRNA as a novel approach for efficient siRNA drug delivery to treat ulcerative colitis.Nanomedicine12,1927-1943 (2017). 
22. Yan, W., Tao, M., Jiang, B., Yao, M., Jun, Y., Dai, W., Tang, Z., Gao, Y., Zhang, L., Chen, X.\&Wang, Q. L. Overcoming drug resistance in colon cancer by aptamer-mediated targeted co-delivery of drug and siRNA using grapefruit-derived nanovectors. Cell Physiol. Biochem. 50,79-91 (2018).

23. Li, Z., Wang, H., Yin, H., Bennett, C., Zhang, H. G.\&Guo, P. Arrowtail RNA for ligand display on ginger exosome-like nanovesicles to systemic deliver siRNA for cancer suppression. Rep.8,14644 (2018).

24. Wang, X., Zhang, M., Flores,S.R.L.,Woloshun, R. R., Yang, C., Yin, L., Xiang, P., Xu, X., Garrick, M. D., Vidyasagar, S., Merlin, D.\&Collins, J. F. Oral gavage of ginger nanoparticle-derived lipid vectors carrying Dmt1 siRNA blunts iron loading in murine hereditary hemochromatosis. Ther.27,493-506 (2019).

25. Ji, Q., Xu, X.\&Wang, K.Genetic transformation of major cereal crops. J. Dev. Biol.57,495-508 (2013).

26. Ranum, P., Rosas, J. P. P.\&Casal,M.N.G. Affiliations expand global maize productionutilizationand consumption. N. Y. Acad. Sci.1312, 105-112 (2014).

27. Zhang, Z., Teotia, S., Tang, J.\& Tang, G. Perspectives on microRNAs and phased small interfering RNAs in maize (Zea mays L.): Functions and big impact on agronomic traits enhancement. Plants (Basel) 8, 170 (2019).

28. Alisa, P., Helen, R.\& Elizabeth, J. J. Xanthophyll (lutein, zeaxanthin) content in fruits, vegetables and corn and egg products. Food Compost. Anal.22, 9-15 (2009).

29. Abdel-Aal,E.S.M.,Akhtar, H., Zaheer, K. \& Ali, R. Dietary sources of lutein and zeaxanthin carotenoids and their role in eye health. Nutrients5,1169-1185 (2013).

30. Grudzinski, W., Piet, M., Luchowski, R., Reszczynska, E., Welc, R., Paduch, R.\&Gruszecki, W. I. Different molecular organization of two carotenoids, lutein and zeaxanthin, in human colon epithelial cells and colon adenocarcinoma cells. Acta A Mol. Biomol. Spectrosc.188,57-63 (2018).

31. El-Sayed, A.\&Harashima, H. Endocytosis of gene delivery vectors: from clathrin-dependent to lipid raft-mediated endocytosis. Ther.21, 1118-1130 (2013).

32. Huang, R., Zhu, G.,Zhang, J., Lai, Y., Xu, Y., He, J.\&Xie, J. Betanodavirus-like particles enter host cells via clathrin-mediated endocytosis in a cholesterol-, $\mathrm{pH}$ - and cytoskeleton-dependent manner. Res.48, 8 (2017).

33. Wang, B., Zhuang, X., Deng, Z. B., Jiang, H., Mu, J., Wang, Q., Xiang, X., Guo, H., Zhang, L., Dryden, G., Yan, J., Miller, D.\&Zhang, H. G. Targeted drug delivery to intestinal macrophages by bioactive nanovesicles released from grapefruit. Ther.22, 522-534 (2014).

34. Weihrauch, J. L.\&Son, Y. S. The phospholipid content of foods.JAOCS60, 12 (1983).

35. Mollinedo, F.\&Gajate, C. Lipid rafts as signaling hubs in cancer cell survival/death and invasion: implications in tumor progression and therapy. Lipid Res.61, 611-635 (2020).

36. Li, Y. C., Park, M. J., Ye, S. K., Kim, C. W. \&Kim, Y. N. Elevated levels of cholesterol-rich lipid rafts in cancer cells are correlated with apoptosis sensitivity induced by cholesterol-depleting agents. $J$. Pathol.168, 1107-1118 (2006). 
37. Kim, K., Yoo, H. J., Jung, J. H., Lee, R., Hyun, J. K., Park, J. H., Na, D.\&Yeon, J. H. Cytotoxic effects of plant sap-derived extracellular vesicles on various tumor cell types. Funct. Biomater.11, 22 (2020).

38. Raimondo, S., Naselli, F., Fontana, S., Monteleone, F., Dico, A. L., Saieva, L., Zito, G., Flugy, A., Manno, M., Bella, M. A. D., Leo, G. D.\& Alessandro, R. Citrus limon-derived nanovesicles inhibit cancer cell proliferation and suppress CML xenograft growth by inducing TRAIL-mediated cell death. Oncotarget 6, 19514-19527 (2015).

39. Frenquelli, M.\&Tonon, G. WNT signaling in hematological malignancies. Front Oncol.10, 615190 (2020).

40. Jourabchin, A., Mazoochi, T., Kashani, H. H.\&Khamechian, T. Assessment of relationship between expression of survivin protein and histopathology diagnosis and malignancy severity in colon specimen. Gastrointest. Cancer51, 76-82 (2020).

41. Kedinger, V.,Meulle, A., Zounib, O., Bonnet, M. E., Gossart, J. B., Benoit, E., Messmer, M., Shankaranarayanan, P., Behr, J. P., Erbacher, P.\&Bellemin,A.L.B. Sticky siRNAs targeting survivin and cyclin B1 exert an antitumoral effect on melanoma subcutaneous xenografts and lung metastases.BMC Cancer13, 338 (2013).

42. Bi, M. C., Rosen, R., Zha, R. Y., McCormick, S. A., Song, E.\&Hu, D. N. Zeaxanthin induces apoptosis in human uveal melanoma cells through bcl-2 family proteins and intrinsic apoptosis pathway. Based Complement Alternat. Med.2013, 205082 (2013).

43. Kavalappa, Y. P., Gopal, S. S.\&Ponesakki, G.Lutein inhibits breast cancer cell growth by suppressing antioxidant and cell survival signals and induces apoptosis. Cell Physiol.236, 1798-1809(2021).

44. Sheng, Y. N., Luo, Y. H., Liu, S. B., Xu, W. T., Zhang, Y., Zhang, T., Xue, H., Zuo, W. B., Li, Y. N., Wang, C. Y.\&Jin, C. H. Zeaxanthin induces apoptosis via ROS-regulated MAPK and AKT signaling pathway in human gastric cancer cells. Onco Targets Ther.13,10995-11006 (2020).

45. Song, X., Li, Y., Cao, X.\&Qi, Y. MicroRNAs and their regulatory roles in plant-environment interactions. Rev. Plant Biol.70, 489-525 (2019).

46. Luo, Y., Wang, P., Wang, X., Wang, Y., Mu, Z., Li, Q., Fu, Y., Xiao, J., Li, G., Ma, Y., Gu, Y., Jin, L., Ma, J., Tang, Q.,Jiang, A., Li, X.\&Li, M. Detection of dietetically absorbed maize-derived microRNAs in pigs. Rep. 7, 645 (2017).

47. Li, M., Chen, T., Wang, R., Luo, J. Y., He, J. J., Ye, R. S., Xie, M. Y., Xi, Q. Y., Jiang, Q. Y., Sun, J. J.\&Zhang,Y. L. Plant miR156 regulates intestinal growth in mammals by targeting the Wnt/ $\beta$-catenin pathway. J. Physiol. Cell Physiol.317, C434-C448 (2019).

48. Chin, A. R., Fong, M. Y., Somlo, G., Wu, J., Swiderski, P., Wu, X.\&Wang, S. E. Cross-kingdom inhibition of breast cancer growth by plant miR159. Cell Res.26, 217-228 (2016).

49. Li, M., Chen, T., He, J. J., Wu, J. H., Luo, J. Y., Ye, R. S., Xie, M. Y., Zhang, H. J., Zeng, B., Liu, J., Xi, Q. Y., Jiang, Q. Y., Sun, J. J.\&Zhang, Y. L. Plant miR167e-5p inhibits enterocyte proliferation by targetingcatenin.Cel/s8, 1385 (2019).

50. Zheng, C., Chen, J., Wu, X.,Wang, X., Zheng, J., Pan, Y., Wang, L.\& Hu, Y. CpG-ODN activation of TLR9 signaling pathways and NF-KB in STZ-induced diabetic rats.Zhonghua Yi Xue Za Zhi94, 3334-3337 
(2014).

51. Holdsworth, S. R.\&Gan, P. Y. Cytokines: names and numbers you should care about. J. Am. Soc. Nephrol.10, 2243-2254 (2015).

52. Akhurst, R. J. Targeting TGF- $\beta$ signaling for therapeutic gain.Cold Spring Harb. Perspect. Biol.9, a022301 (2017).

53. Mu, J., Zhuang, X., Wang, Q., Jiang, H., Deng, Z. B., Wang, B., Zhang, L., Kakar, S., Jun, Y., Miller, D.\&Zhang, H. G. Interspecies communication between plant and mouse gut host cells through edible plant derived exosome-like nanoparticles. Nutr. Food Res.58, 1561-1573 (2014).

54. Cao, M., Yan, H., Han, X., Weng, L.,Wei, Q., Sun, X., Lu, W., Wei, Q., Ye, J., Cai, X., Hu, C., Yin, X.\&Cao, P.Ginseng-derived nanoparticles alter macrophage polarization to inhibit melanoma growth. Immunother. Cancer7, 326 (2019).

55. Yahaya,M.A.F.,Lila,M.A.M.,Ismail, S., Zainol, M.\&Nik Mohd Afizan, N. A. R. Tumor-associated macrophages (TAMs) in colon cancer and how to reeducate them. Immunol. Res.2019, 2368249 (2019).

56. Thanaketpaisarn, O., Nishikawa, M., Okabe, T., Yamashita, F.\&Hashida, M. Insertion of nuclear factorkappaB binding sequence into plasmid DNA for increased transgene expression in colon carcinoma cells. Biotechnol.133, 36-41 (2008).

57. Zhang, H. Thin-film hydration followed by extrusion method for liposome preparation.Methods Mol. Biol.1522, 17-22 (2017).

58. Bradford,M.M. A rapid and sensitive method for the quantitation of microgram quantities of protein utilizing the principle of protein-dye binding. Biochem. 72, 248-254 (1976).

59. Ovejera, A. A., Houchens, D. P.\&Barker, A. D. Chemotherapy of human tumor xenografts in genetically athymic mice.Ann. Clin. Lab Sci.8, 50-56 (1978).

\section{Tables}

Table 1. Characteristics of cNPs or PC-Lip

\begin{tabular}{|llll|}
\hline NPs & $\begin{array}{l}\text { Particle size } \\
(\mathrm{nm})\end{array}$ & Zeta potential $(\mathrm{mV})$ & $\begin{array}{l}\text { Particle number } \\
\left(\times 10^{10} \text { particles } / 100 \mathrm{~g} \mathrm{corn}\right)\end{array}$ \\
\hline CNPs & $83.3 \pm 22.2$ & $-17.4 \pm 1.8$ & $2130 \pm 117$ \\
\hline PC-Lip & $83.6 \pm 5.7$ & $5.28 \pm 0.2$ & -
\end{tabular}

Results are expressed as the mean \pm standard deviation (SD) of three independent experiments.

\section{Figures}


(A)

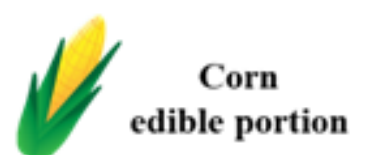

Homogenization

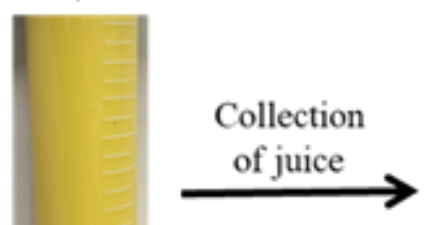

Centrifugation

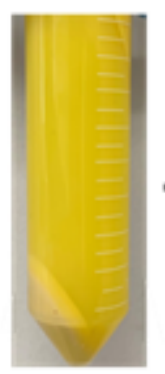

Collection of supernatant/ filtration through a $0.45 \mu \mathrm{m}$ filter

Loaded on sucrose cushion

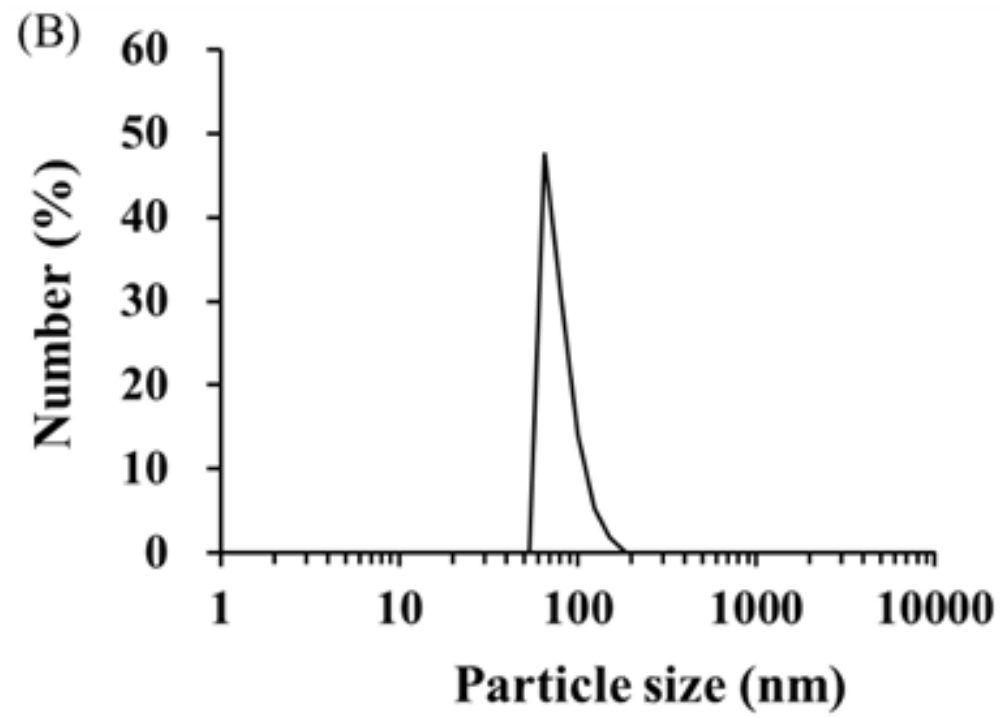

(C)
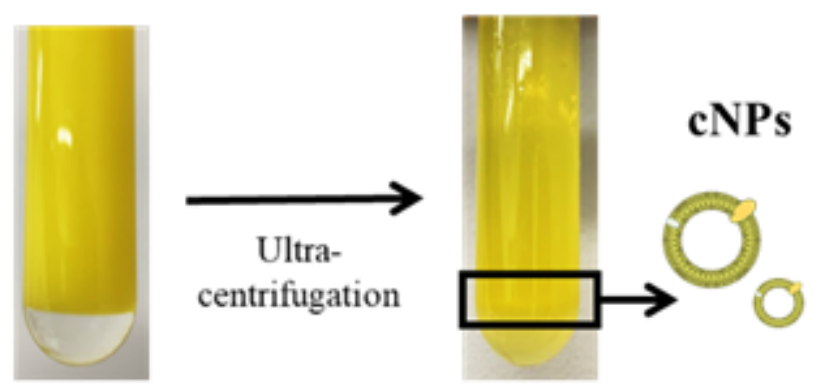

Ultraentrifugation

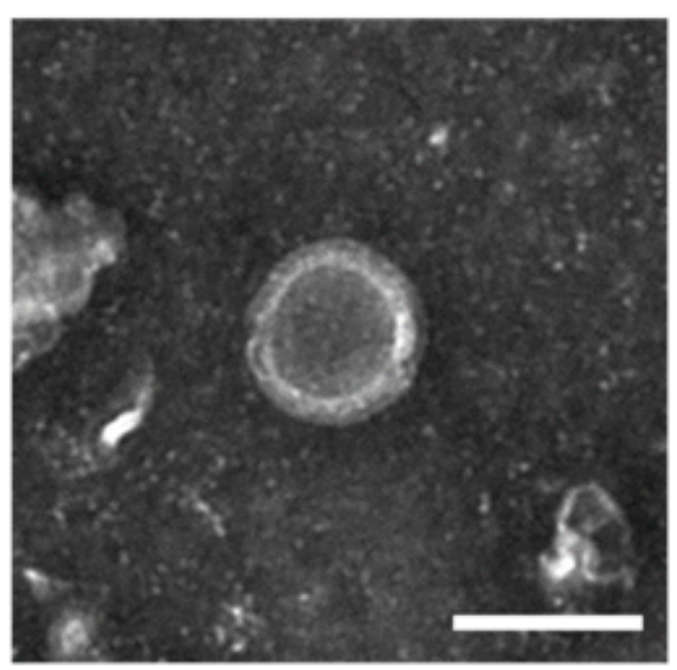

\section{Figure 1}

Preparation and characterization of cNPs. (A) Flow diagram of cNPs preparation. Corn homogenate was obtained from edible portion of corn using a food processor. The homogenate was centrifuged, filtrated, and ultracentrifuged using sucrose cushion. cNPs were then collected from the indicated phase (black rectangle). (B) Size distribution of cNPs was determined using ELSZ-2000ZS. (C) TEM image of cNPs was observed using $\mathrm{H}-7650$ TEM. 
(A)

(B)

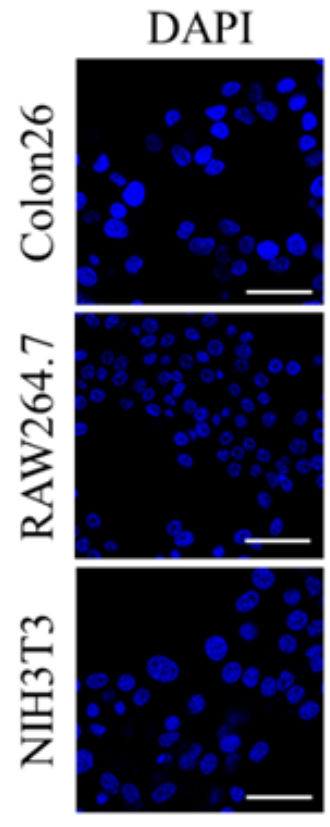

(C)
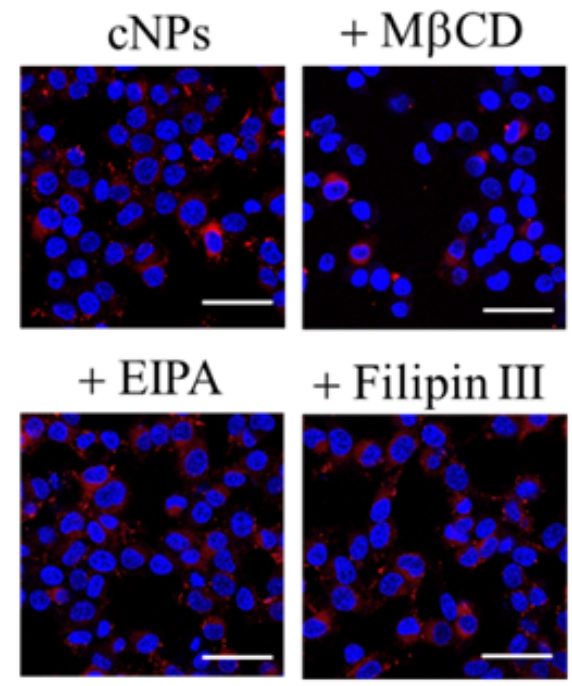
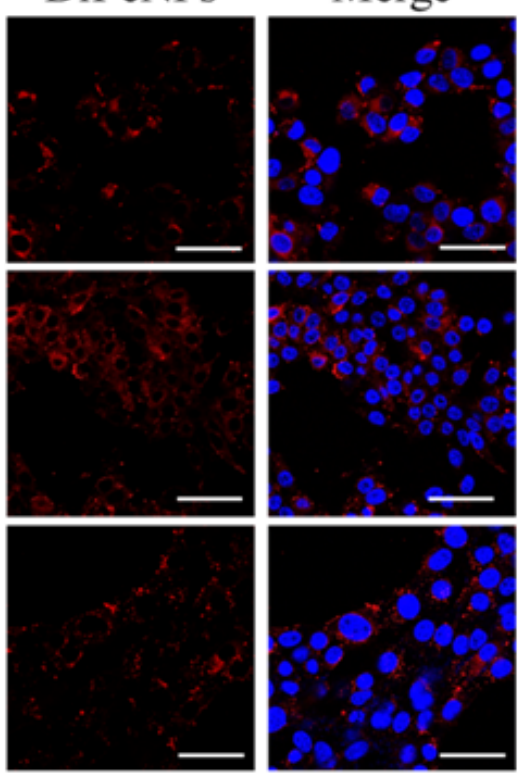

(D)
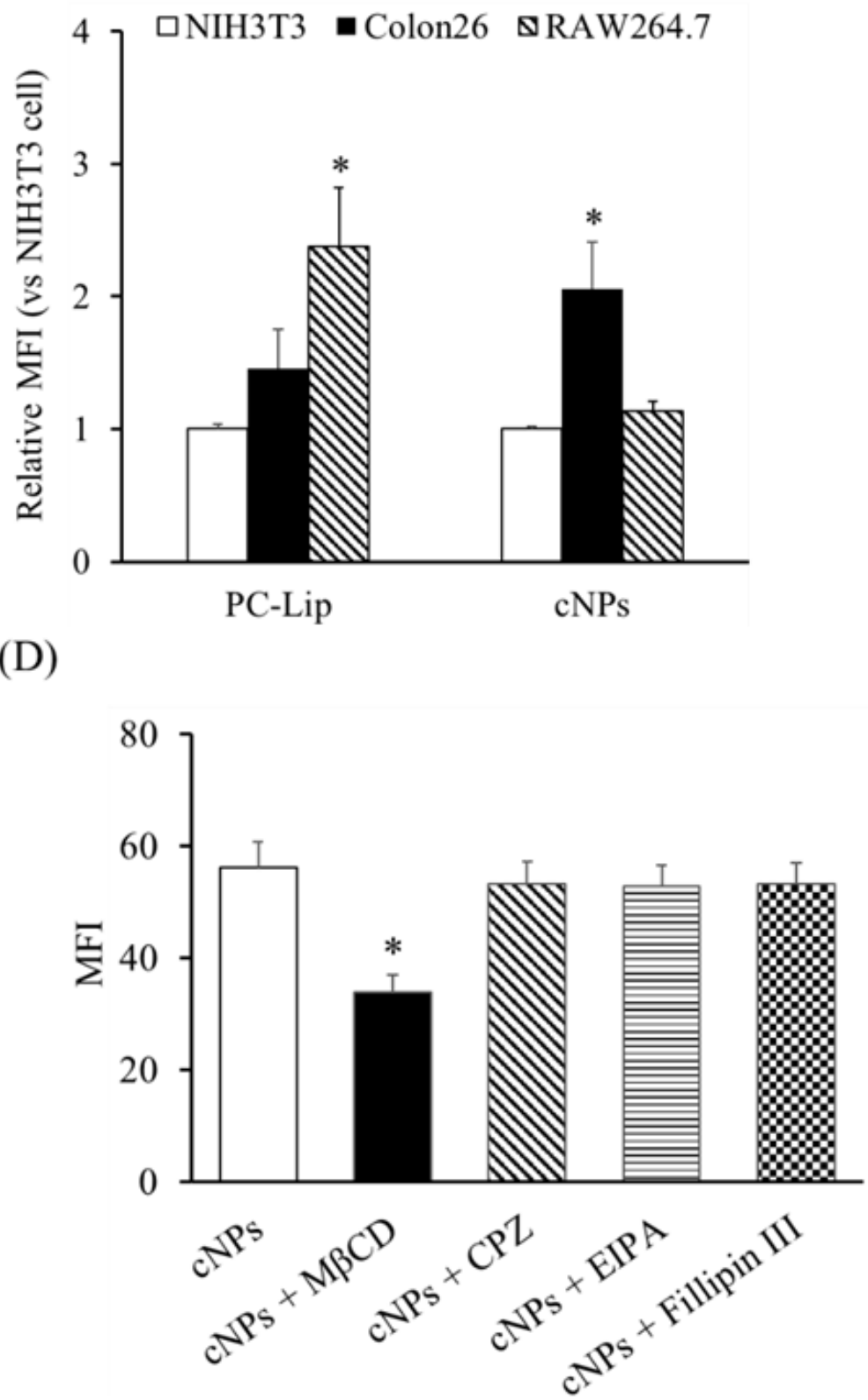

Figure 2

Cellular uptake of cNPs via endocytosis pathway. (A) Confocal microscopic images of Dil-labeled cNPs taken up by colon26, NIH3T3, and RAW264.7 cells. Cells were incubated with Dil-labeled cNPs for $3 \mathrm{~h}$.

Scale bars indicate $50 \mu \mathrm{m}$. (B) Quantitative flow cytometric analysis of cellular uptake of Dil-labeled cNPs or PC-Lip. The cells were incubated with Dil-labeled CNPs or PC-Lip for $3 \mathrm{~h}$ at $37^{\circ} \mathrm{C}$ and fixed using PFA. MFI of CNPs or PC-Lip in the cells was quantified by flow cytometry. Results are expressed as the mean \pm SD of three samples. ${ }^{*} p<0.05$ vs. NIH3T3 cell group. (C) Colon26 cells were incubated with endocytosis inhibitors $(0.5 \mu \mathrm{g} / \mathrm{mL}$ Filipin III, $30 \mu \mathrm{M} \mathrm{CPZ}, 40 \mu \mathrm{M}$ EIPA, and $10 \mathrm{mM} \mathrm{M \beta CD})$ for 40 min and then incubated with Dil-labeled cNPs for $3 \mathrm{~h}$. Cells were fixed and imaged by confocal laser scanning 
microscopy. Scale bars indicate $50 \mu \mathrm{m}$. (D) Quantitative flow cytometric analysis of Dil-labeled cNPs taken up by colon 26 cells. Endocytosis inhibitors $(0.5 \mu \mathrm{g} / \mathrm{mL}$ Filipin III, $30 \mu \mathrm{M} \mathrm{CPZ}, 40 \mu \mathrm{M}$ EIPA, and 10 $\mathrm{mM} M \beta C D$ ) were added to colon26 cells and incubated for $40 \mathrm{~min}$. The cells were incubated with Dillabeled cNPs for $3 \mathrm{~h}$ at $37^{\circ} \mathrm{C}$ and fixed using PFA. MFI of cNPs in colon26 cells was quantified by flow cytometry. Results are expressed as the mean \pm SD of three samples. ${ }^{*} p<0.05$ vs. cNPs group.

(A)

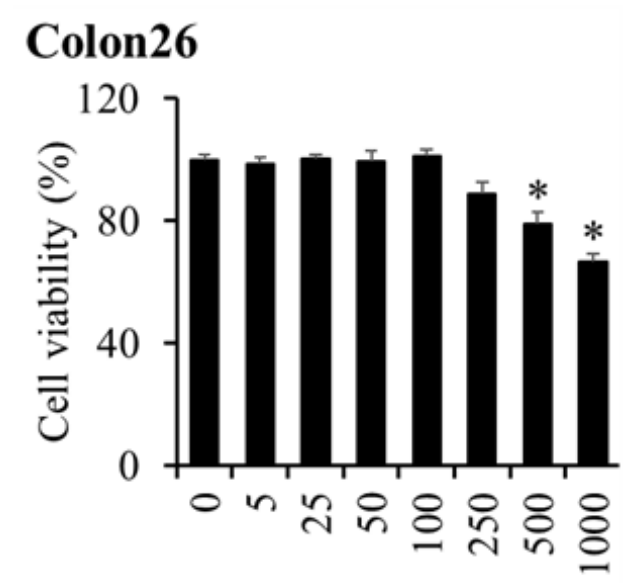

cNPs $(\mu \mathrm{g} / \mathrm{mL})$

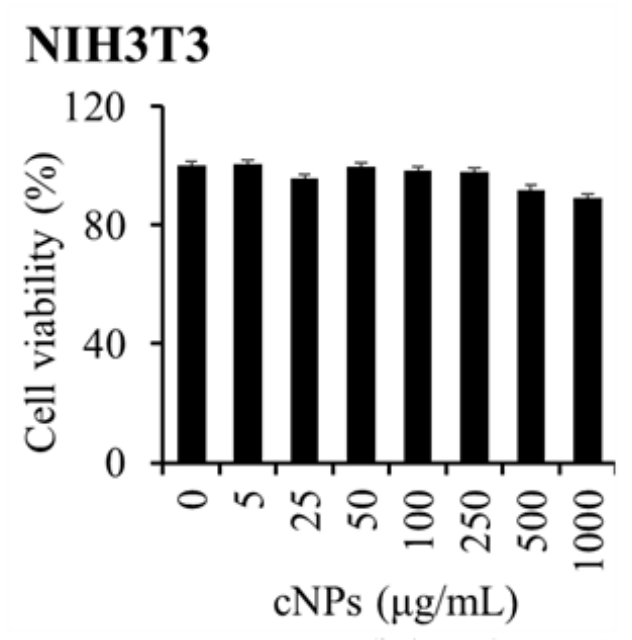

NIH3T3

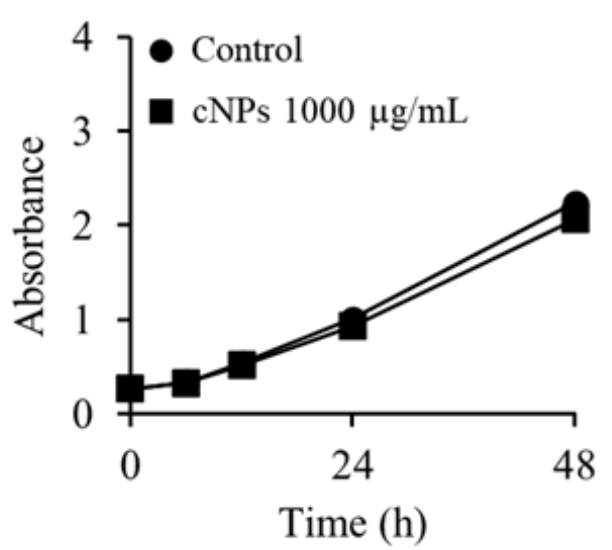

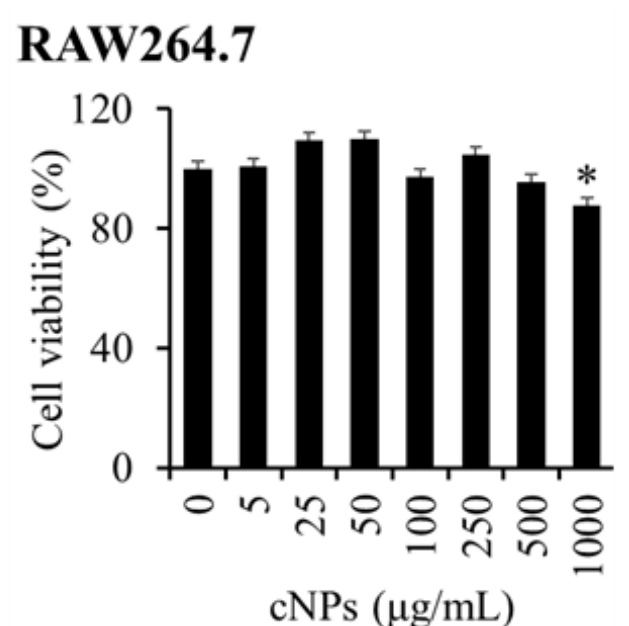

RAW264.7

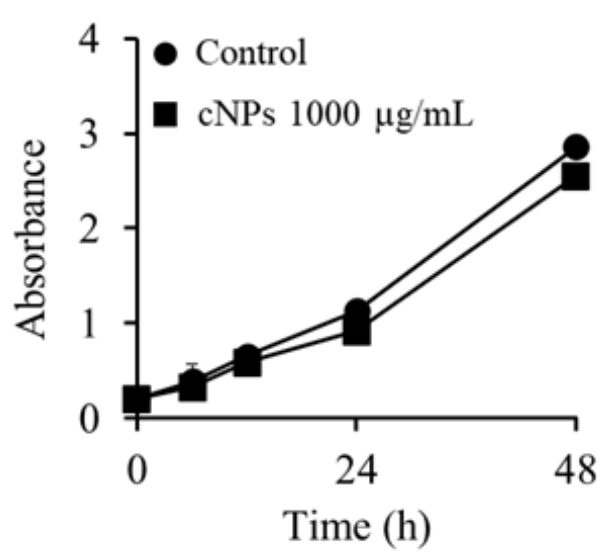

Figure 3

Cell number and proliferation after incubation with cNPs. (A) Cell number was measured by CCK8 assay after $24 \mathrm{~h}$ of cNPs addition. Colon26, NIH3T3, and RAW264.7 cells were incubated with $5-1000 \mu \mathrm{g} / \mathrm{mL}$ of cNPs. Results are expressed as the mean \pm SD of four samples. ${ }^{*} p<0.05 \mathrm{vs.} 0 \mu \mathrm{g} / \mathrm{mL} \mathrm{cNPs}$ group(the control group). (B) Cell proliferation was measured by CCK8 assay after 6, 12, 24 and $48 \mathrm{~h}$ of 1000 $\mu \mathrm{g} / \mathrm{mL} \mathrm{cNPs}$ addition. Results are expressed as the mean \pm SD of four samples. ${ }^{*} \mathrm{p}<0.05 \mathrm{vs}$. control group. 

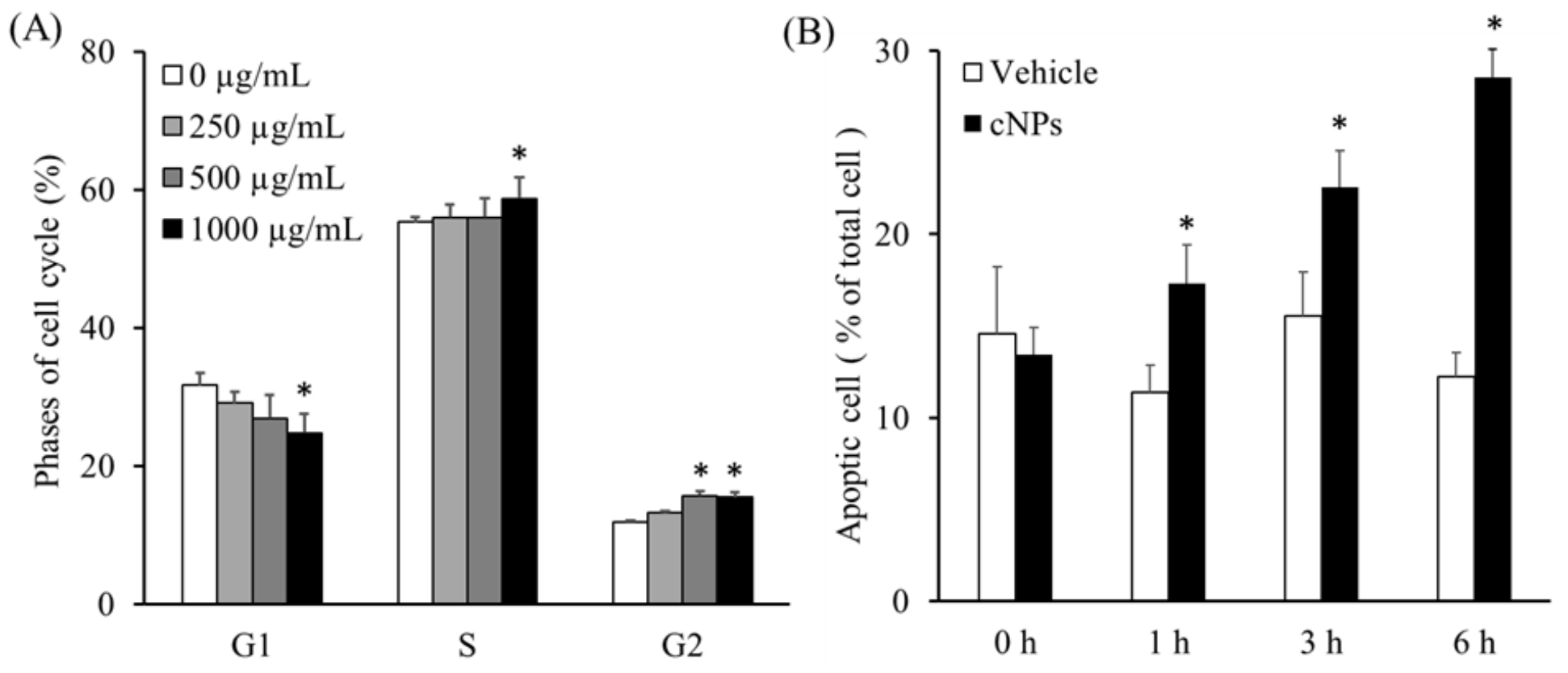

Figure 4

Cell cycle and apoptosis analysis after incubation with cNPs. (A) Colon26 cells were incubated with 250, 500 , and $1000 \mu \mathrm{g} / \mathrm{mL}$ of cNPs. At 1,3, and $6 \mathrm{~h}$ after incubation, the cells were stained with PI. Then, cell cycle analysis was performed by flow cytometry. Results are expressed as the mean \pm SD of four samples. ${ }^{*} \mathrm{p}<0.05 \mathrm{vs} .0 \mu \mathrm{g} / \mathrm{mL}$ cNPs group(the control group). (B) Colon26 cells were incubated with $1000 \mu \mathrm{g} / \mathrm{mL}$ cNPs or PBS (vehicle). At 1, 3, and $6 \mathrm{~h}$ after incubation, the apoptotic cells were stained with $\mathrm{PI}$ and detected by flow cytometry. Results are expressed as the mean \pm SD of four samples. ${ }^{\star} \mathrm{p}<0.05$ vs. vehicle group.

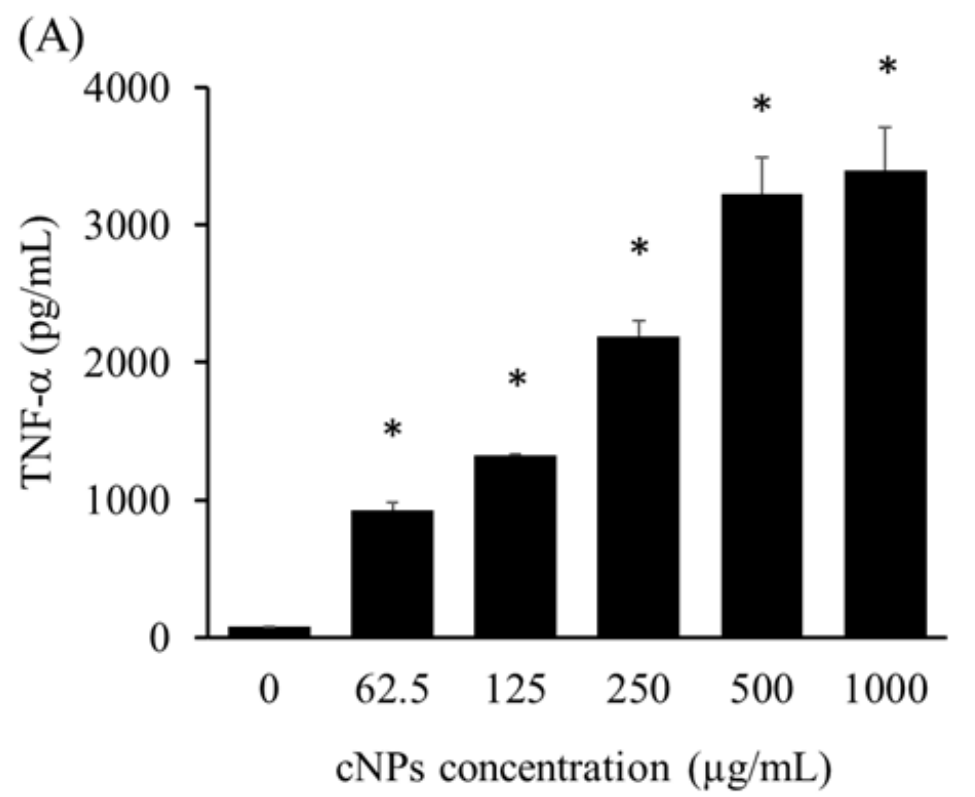

(B)

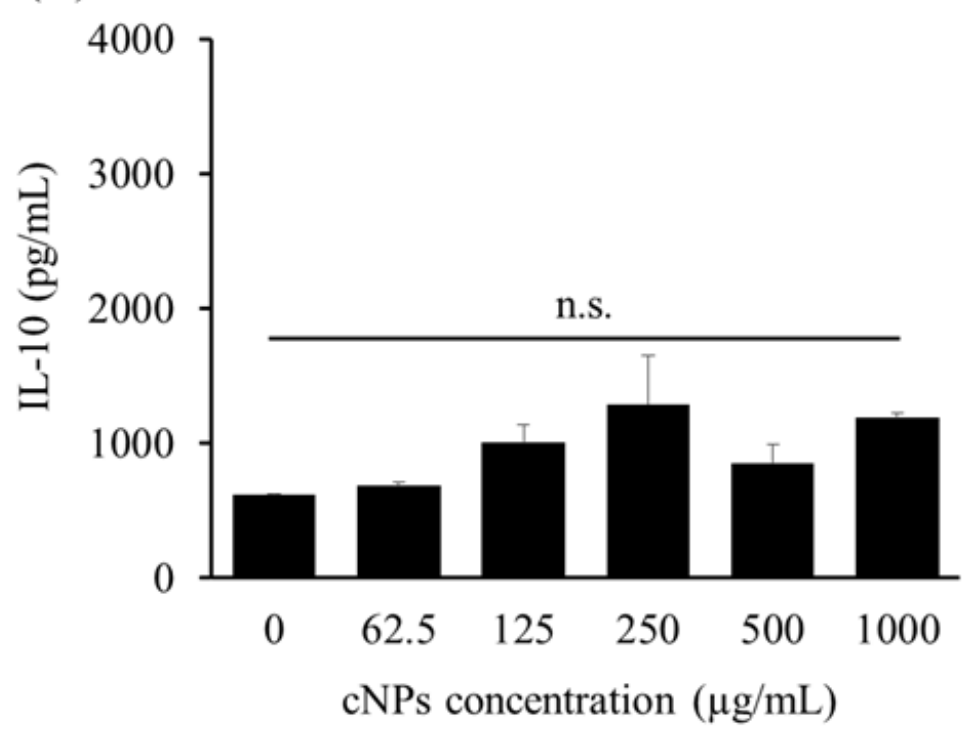

Figure 5 
Cytokine release from RAW264.7 cells. (A) TNF-a and (B) IL-10 production from RAW264.7 cells after cNPs addition. The supernatants of RAW264.7 cells after $24 \mathrm{~h}$ of cNPs addition were collected for ELISA. Results are expressed as the mean \pm SD of three samples. ${ }^{*} p<0.05 \mathrm{vs} .0 \mu \mathrm{g} / \mathrm{mL}$ cNPs group(the control group). n.s.; not significant.

(A)

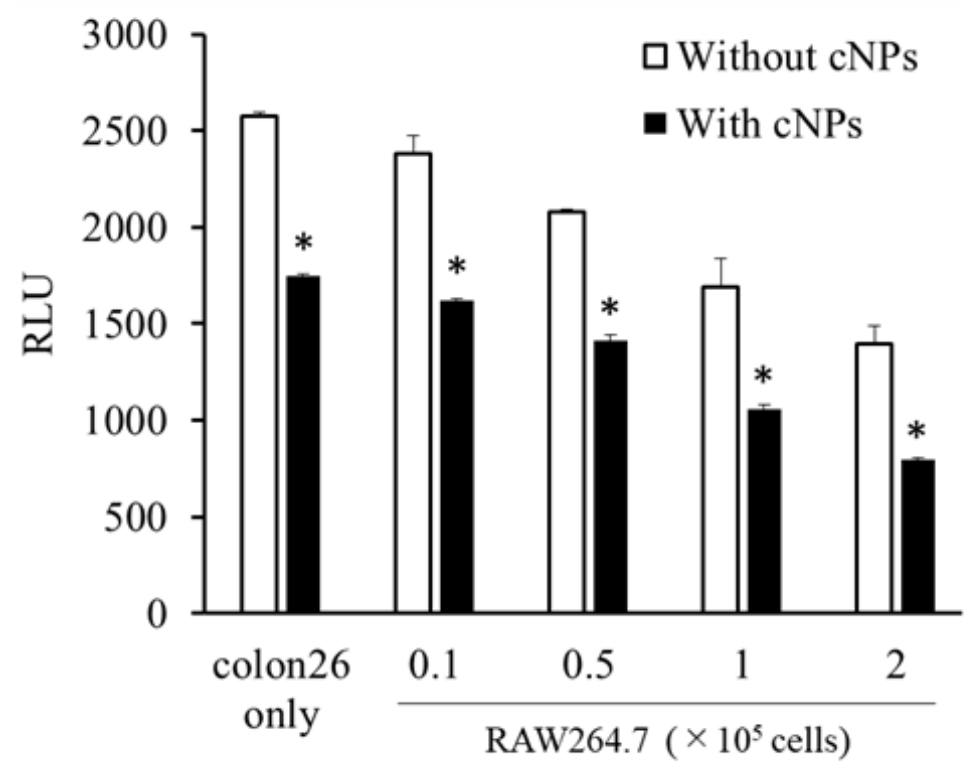

(B)

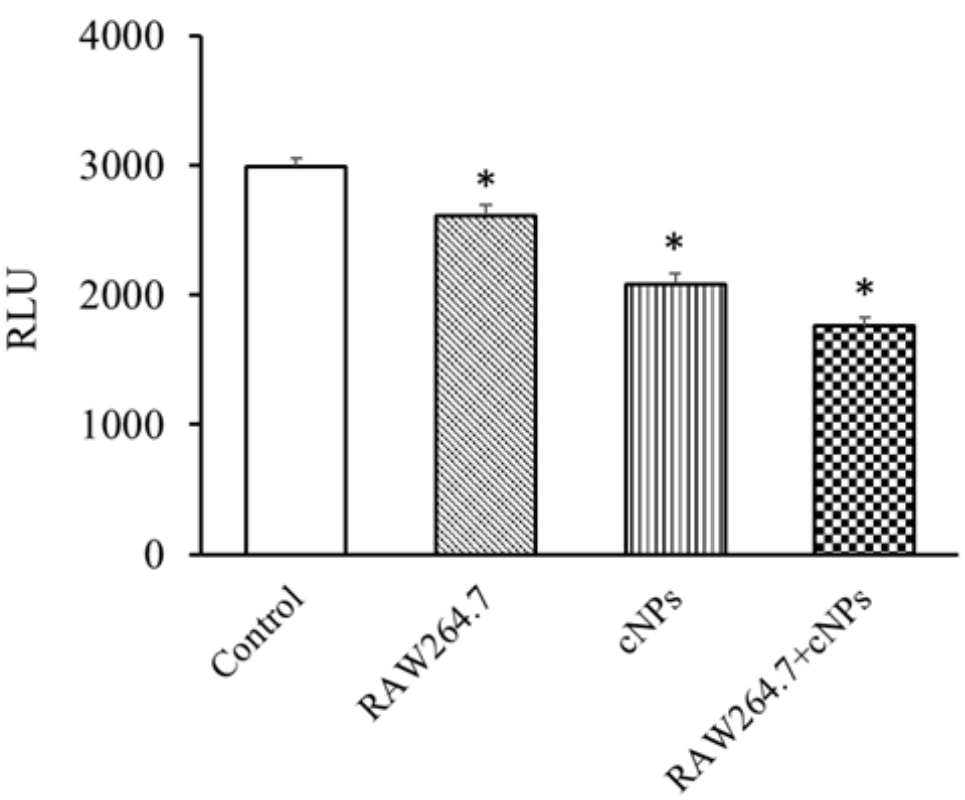

Figure 6

Combined effect of cNPs and RAW264.7 cells on the proliferation of colon26/fluc cells. (A) Co-incubation of RAW264.7 cells with colon26/fluc cells with or without cNPs. After 24 h-incubation, cells were lysed, and luciferase activity was measured. Results are expressed as the mean \pm SD of three samples. ${ }^{*} p<$ 0.05 vs. without cNPs (no treatment) group. (B) Colon26/fluc cells were seeded onto the bottom of Transwell, and RAW264.7 cells with or without cNPs were added to the insert well (upper bottom). After $24 \mathrm{~h}$-incubation, colon26/fluc cells were lysed and luciferase activity was measured. Results are expressed as the mean \pm SD of three samples. ${ }^{\star} p<0.05$ vs. control group. 
(A)

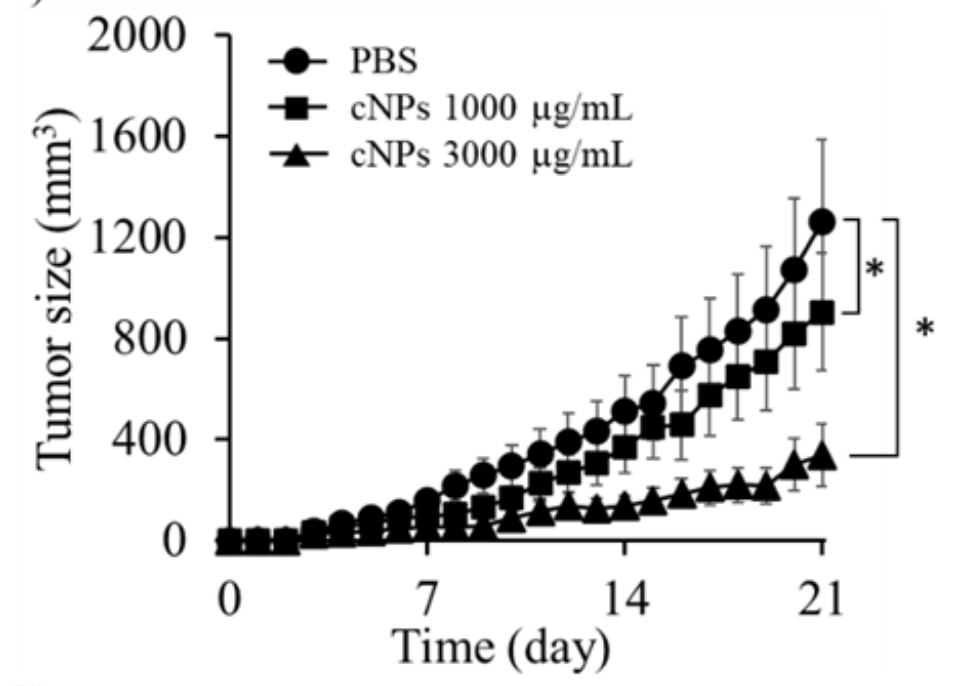

(B)

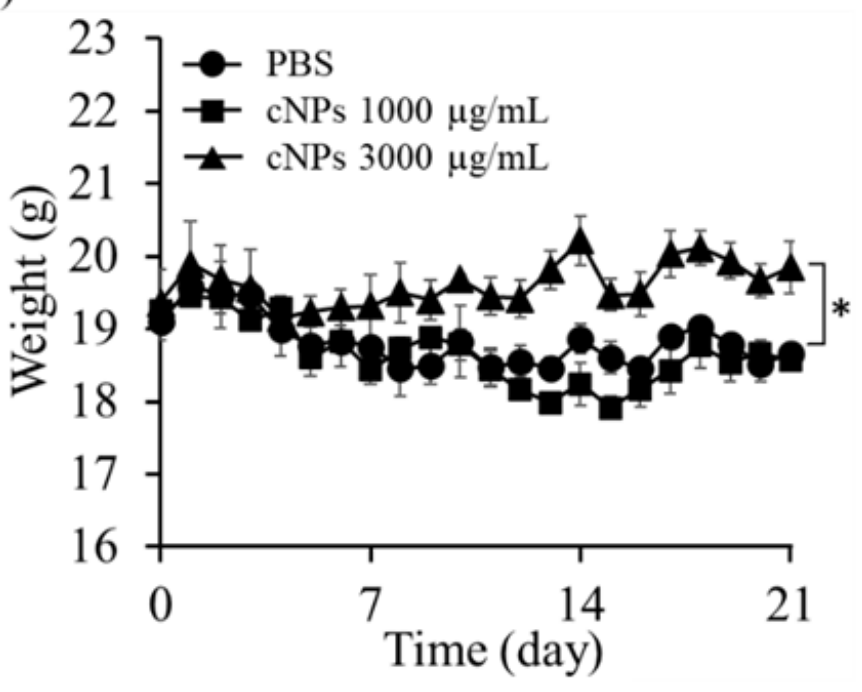

(C)
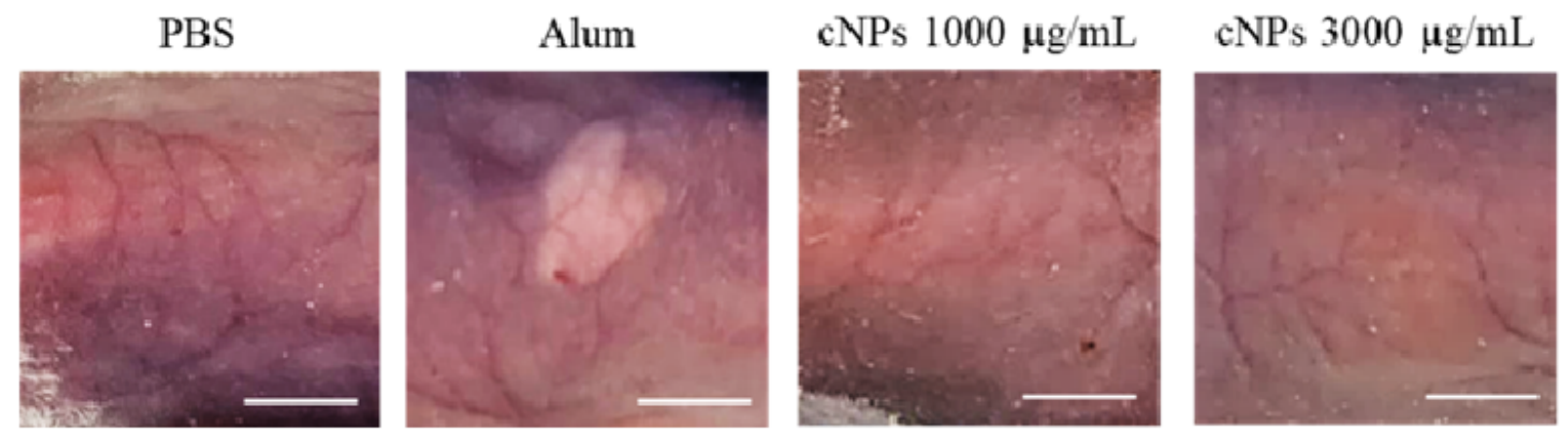

Figure 7

Tumor growth suppression in tumor-bearing mice after cNPs administration. (A) Tumor size in tumorbearing mice. Colon 26 cells were subcutaneously injected into the back area of BALB/c mice. After the tumor size reached $50 \mathrm{~mm} 3$, cNPs at concentrations of 1000 or $3000 \mu \mathrm{g} / \mathrm{mL}(50 \mu \mathrm{L})$ were intratumorally administered every day. Results are expressed as the mean \pm SD of three mice. ${ }^{*} p<0.05$ vs. PBS group.

(B) Body weight changes in different treatment groups. The change of body weight in tumor-bearing mice after cNPs treatment. Results are expressed as the mean \pm SD of three mice. ${ }^{*} p<0.05$ vs. PBS group. (C) Skin inflammation in mice after cNPs administration. 1000 or $3000 \mu \mathrm{g} / \mathrm{mL} c N P s$, alum, and PBS (50 $\mu \mathrm{L})$ were subcutaneously administered into the back area of BALB/c mice. After $24 \mathrm{~h}$, the skin was observed. Scale bars indicate $5 \mathrm{~mm}$. 